\title{
Cadmium and Zinc Concentration in Grain of Durum Wheat in Relation to Phosphorus Fertilization, Crop Sequence and Tillage Management
}

\author{
Xiaopeng Gao and Cynthia A. Grant \\ Agriculture and Agri-Food Canada, Brandon Research Centre, 2701 Grand Valley Road, Brandon, MB, Canada R7A 5Y3 \\ Correspondence should be addressed to Cynthia A. Grant, cynthia.grant@agr.gc.ca
}

Received 16 November 2011; Revised 3 January 2012; Accepted 7 January 2012

Academic Editor: Philip White

Copyright $\odot 2012$ X. Gao and C. A. Grant. This is an open access article distributed under the Creative Commons Attribution License, which permits unrestricted use, distribution, and reproduction in any medium, provided the original work is properly cited.

\begin{abstract}
Field experiments were conducted at two locations in Manitoba, Canada, to determine the effect of crop rotation, phosphorus (P) fertilization and tillage on grain yield and grain concentrations of $\mathrm{Cd}$ and $\mathrm{Zn}$ in durum wheat (Triticum durum L.). Compared to conventional tillage (CT), reduced tillage (RT) management decreased grain Cd and increased grain yield and grain $\mathrm{Zn}$ in half of the site-years. The type of preceding crops of spring wheat-flax or canola-flax had little influence. Rate and timing of $\mathrm{P}$ application had little effect on grain Cd, but increasing $\mathrm{P}$ rate tended to decrease grain $\mathrm{Zn}$. No interactive effect was detected among tested factors. Grain Zn was not related to grain Cd, but positively to other nutrients such as Fe, Mn, P, Ca, K, and Mg. Both grain Zn and Fe correlated positively with grain protein content, suggesting protein may represent a sink for micronutrients. The study suggested that the tillage management may have beneficial effects on both grain yield and quality. Phosphorus fertilizer can remain available for subsequent crops and high annual inputs in the crop sequence may decrease crop grain $\mathrm{Zn}$. Understanding the environment is important in determining the impact of agricultural management on agronomic and nutrient traits.
\end{abstract}

\section{Introduction}

Cadmium (Cd) accumulation in soils and cereal crops and its transfer to the human diet is a widespread problem around the world. Durum wheat (Triticum durum L.) is of particular concern because it accumulates more $\mathrm{Cd}$ than the other commonly grown cereals with accumulation increasing in the order of rye $<$ barley $<$ oats $<$ bread wheat $<$ durum wheat [1]. Cadmium concentration in durum wheat grain harvested on Canadian prairies have been reported to range from less than 50 to more than $300 \mu \mathrm{g} \mathrm{kg}^{-1}$ [2], at times exceeding the $200 \mu \mathrm{g} \mathrm{kg}^{-1}$ limit set by the Codex Alimentarius Commission [3]. In addition, approximately $2.1 \times 10^{6}$ ha durum wheat, which occupies $10 \%$ of worldwide durum production area, is grown in the western Prairie region of Canada [4]. Therefore, there is a desire in the Canadian farming industry to control the Cd levels in the durum grain, either by improved agricultural management practices [5] or by breeding low $\mathrm{Cd}$-accumulating cultivars $[6,7]$.
Accumulation of metal elements in crop grains can be regulated by several physiological processes, including uptake from the soil solution, root-to-shoot translocation, and retranslocation into the grain during maturation. Zinc $(\mathrm{Zn})$ and $\mathrm{Cd}$ are chemically similar and can compete for common transport mechanisms for uptake and translocation in the crop [5]. In contrast to $\mathrm{Cd}, \mathrm{Zn}$ concentrations in grains of cereal crops such as wheat are often lower than desired level as sources of minerals for the human diet [8]. High consumption of cereal-based foods with low $\mathrm{Zn}$ concentration can result in $\mathrm{Zn}$ malnutrition in human. On the Canadian prairies, $\mathrm{Zn}$ concentration in wheat grain generally ranges between 20 and $30 \mathrm{mg} \mathrm{kg}^{-1}$ [9]. These concentrations are not adequate for human nutrition in diets with wheat constituting the main source of essential minerals [8]. Therefore, it is desirable to increase the $\mathrm{Zn}$ concentration in wheat grain to reduce the risk of $\mathrm{Zn}$ deficiency in the human diet.

Phosphorus fertilizer is a major input for crop production. The fertilizer efficiency, however, is often quite low 
during the season of application because of the low mobility and rapid immobilization of phosphate after being applied to the soil. Application of $\mathrm{P}$ fertilizer can influence soil $\mathrm{Cd}$ availability and $\mathrm{Cd}$ accumulation in crops, either by direct addition of $\mathrm{Cd}$ as a contaminant in $\mathrm{P}$ fertilizers, or by indirect impact on soil properties, plant nutrition, and plant growth $[5,10]$. For example, application of high-Cd P fertilizers led to increases in soil and plant $\mathrm{Cd}$ in many long-term field studies [11-13]. Phosphorus fertilizer is also frequently reported to reduce $\mathrm{Zn}$ concentration in crops and potential mechanisms include interactions between $\mathrm{Zn}$ and $\mathrm{P}$ in the soil [14], less translocation of $\mathrm{Zn}$ from the roots to the shoots [15], metabolic disorder within plant cells [16], and dilution effect [17]. In a short-term growth chamber study [18], the immediate increase of $\mathrm{Cd}$ accumulation in durum wheat following phosphate application was mostly due to increased Cd uptake and translocation by decreasing $\mathrm{Zn}$ accumulation in durum wheat induced by $\mathrm{P}$ fertilization, rather than to a direct addition effect. Similar results were also reported in other studies $[19,20]$, where using reagentgrade phosphate increased $\mathrm{Cd}$ concentration, but decreased Zn concentration of durum wheat. Though these studies showed the long-term or short-term effect of $\mathrm{P}$ fertilization on phytoavailability of $\mathrm{Cd}$ and $\mathrm{Zn}$ in soil-plant system, there is little information available on the effect of the residual $\mathrm{P}$ from $\mathrm{P}$ fertilizer that was applied to preceding crops.

On the Canadian prairies, rotation of wheat with oilseeds or pulse crops is widely adopted and has been reported to increase grain yield and quality of subsequent crops through reduced disease incidence, improved water use efficiency, soil physical and chemical properties, and enhanced soil ecological environments [21-23]. Several studies have addressed the impact of crop rotation on Cd concentration in crops. Oliver et al. [24] reported a greater $\mathrm{Cd}$ concentration in spring wheat grown after lupin than after cereal and proposed the effect was due to increased $\mathrm{Cd}$ availability by rhizosphere acidification and root release of citric acid in lupin. In a 3year field trial in Manitoba,Canada, seed Cd concentration in flax was lower when grown after bread wheat (Triticum aestivum L.) than after canola (Brassica napus L.), which was attributed to an increase in mycorrhizal colonization or to the lower $\mathrm{Cd}$ concentration in the decomposing wheat residue relative to canola residue [25].

Reduced tillage practices are widely adopted by farmers on the Canadian prairies because of the benefits in conserving soil moisture, preventing soil erosion and reducing cost of production [26]. Difference in tillage management may have an impact on $\mathrm{pH}$ and nutrient stratification in the soil profile or residue decomposition [27], and consequently affect availability of $\mathrm{Cd}$ and $\mathrm{Zn}$. The effect of tillage management on uptake of $\mathrm{Cd}$ and $\mathrm{Zn}$ in crops has been investigated in several field studies and the results are inconsistent. Tiller et al. [28] reported a 30\% greater Cd concentration in spring wheat grain under direct drilling, compared to reduced tillage. Franzluebbers and Hons [29] reported that soil under a no-tillage system contained greater amounts of extractable $\mathrm{Zn}$ than under a conventional tillage system. In some other field studies, however, long-term tillage practices did not consistently influence $\mathrm{Cd}$ concentration in soils and crops $[25,30,31]$.

Information on the influence of agricultural management practices on crop yield and on $\mathrm{Cd}$ and $\mathrm{Zn}$ concentration and accumulation in crops is important in order to select management practices that optimize both crop productivity and quality. Although many studies have evaluated the impact of tillage system, crop sequence and fertilizer practices in the short term, effects of these management practices can persist and have impacts on subsequent crops. For example, P fertilizer not used by a crop in the year of production will remain in the soil and may exert residual effect on the following crop. Effects of tillage may increase over time as changes in soil organic matter and nutrient stratification intensify. However, information on the persistence of management effects on the yield and quality of later crops in a cropping system are limited.

Based on field studies conducted at two locations over a four-year period, yield and concentrations of $\mathrm{Cd}$ and $\mathrm{Zn}$ of flax were shown to be influenced by tillage system, type of preceding crop and $\mathrm{P}$ application to the preceding crop [25, 32], but information is lacking about whether such effects can persist to influence subsequent crops. Therefore, to address this question, the field study described by Grant et al. $[25,32]$ was extended for an additional year to determine if preceding crop, P fertilization and tillage system would have a continuing effect on the yield and quality of the durum wheat grown in the third year of the cropping sequence.

\section{Materials and Methods}

2.1. Experimental Treatment and Cultural Practices. Field plot experiments were conducted at two different locations near Brandon, Manitoba. Both sites were classified as clay loam, Orthic Black Chernozemic soils. Initial characteristics of the soils are provided in Table 1 [25]. Sampling and determination methods for soil characteristics were also described by Grant et al. [25]. One site (MZTRF) had been under reduced tillage (RT) management for 6 years before the study was initiated, while the second site (BRC North) had been under conventional tillage (CT) management until the establishment of the study. Neither of the soils was industrially contaminated and as such both are representative of soils commonly used for durum wheat production on the Canadian prairies.

The study was conducted over a 5 yr period from 19992003, with 3 yr cropping cycles being conducted at each of two locations in 1999-2000-2001, 2000-2001-2002, and 2001-2002-2003.

In the first phase of the $3 \mathrm{yr}$ cycle, either spring wheat (cv. AC Barrie) or canola (cv. G3295) was seeded under CT or RT, with P fertilizer treatments of 0,11 and $22 \mathrm{~kg} \mathrm{P} \mathrm{ha}^{-1}$ as monoammonium phosphate (MAP). In the second phase, each plot where wheat or canola had been grown in the preceding season was divided into two subplots. Flax (cv. AC Emerson) was seeded into each subplot, with $\mathrm{P}$ fertilizer treatment of 0 or $11 \mathrm{~kg} \mathrm{P} \mathrm{ha}^{-1}$. Tillage treatment was kept the same as the preceding season. For the first and second phases, spring wheat, canola, and flax were harvested at maturity 
TABLE 1: Soil characteristics of the experimental sites prior to initiation of the study.

\begin{tabular}{lccccccc}
\hline \multirow{2}{*}{ Soil property } & Soil depth $(\mathrm{cm})$ & \multicolumn{3}{c}{ BRC North } & \multicolumn{3}{c}{ MZTRF } \\
& & $2001^{*}$ & 2002 & 2003 & 2001 & 2002 & 2003 \\
\hline $\mathrm{pH}$ & $0-15$ & 7.82 & 8.37 & 7.83 & 8.43 & 7.87 & 7.54 \\
& $15-30$ & - & - & 8.17 & - & - & 7.71 \\
& $30-60$ & - & - & 8.43 & - & - & 7.95 \\
& $0-15$ & 290 & 289 & 603 & 261 & 293 & 585 \\
$\mathrm{EC}\left(\mu \mathrm{S} \mathrm{cm}^{-1}\right)$ & $15-30$ & 218 & 290 & 537 & 228 & 228 & 495 \\
& $30-60$ & 299 & 419 & 560 & 226 & 276 & 523 \\
& $0-15$ & 8.34 & 3.78 & 2.50 & 7.92 & 4.19 & 7.50 \\
$\mathrm{~N}\left(\mathrm{mg} \mathrm{kg}^{-1}\right)$ & $15-30$ & 3.31 & 2.56 & 2.75 & 3.42 & 2.03 & 3.19 \\
& $30-60$ & 2.41 & 3.56 & 1.17 & 2.92 & 1.81 & 1.81 \\
$\mathrm{P}\left(\mathrm{mg} \mathrm{kg}^{-1}\right)$ & $0-15$ & 12.53 & 11.63 & 6.75 & 9.36 & 11.34 & 9.94 \\
$\mathrm{~K}\left(\mathrm{mg} \mathrm{kg}^{-1}\right)$ & $0-15$ & 267 & 202 & 259 & 9.36 & 298 & 290 \\
DTPA-Cd $\left(\mu \mathrm{g} \mathrm{kg}^{-1}\right)$ & $0-15$ & 102.6 & 73.3 & 72.0 & 89.6 & 134.8 & 103.6 \\
DTPA-Zn $\left(\mathrm{mg} \mathrm{kg}^{-1}\right)$ & $0-15$ & 0.77 & 0.60 & 0.80 & 1.01 & 1.08 & 1.20 \\
\hline
\end{tabular}

* Soil samples were taken in the first phase of the study, prior to seeding the preceding canola and wheat.

with a plot combine and the crop residue was chopped and returned to the plot where it had originated. Details on the cultural practices and sampling are available by Grant et al. $[25,32]$.

In the third phase, each subplot where flax had been grown in the preceding season was seeded with durum wheat (cv. AC Avonlea). Ammonium nitrate was banded in all subplots prior to seeding at a rate of $100 \mathrm{~kg} \mathrm{~N} \mathrm{ha}^{-1}$, adjusted for the amount of N added in the MAP. Each subplot where no $\mathrm{P}$ was applied in the preceding season received $11 \mathrm{~kg} \mathrm{P}$ $\mathrm{ha}^{-1}$ side-banded as MAP, whereas the subplots where $11 \mathrm{~kg}$ $\mathrm{P} \mathrm{ha}^{-1}$ was applied in the preceding season received no P. This provided a comparison between the effects of $\mathrm{P}$ applied in the current season and the residual effects of $\mathrm{P}$ applied in the previous year. Again, tillage treatment was continued as in the preceding season. Therefore, as shown in Table 2, the experimental design was comprised of two tillage system, two crop rotation, and six P fertilizer treatments, for a total of 24 combinations. The 3 yr cycle of spring wheat-flax-durum wheat or canola-flax-durum wheat was repeated three times at each site. This paper reports data on durum wheat over three growing seasons (2001-2003) on two sites, for a total of 6 site-years.

The treatments, with four replicates, were arranged as a randomized complete block, with a split-plot layout for a total of 96 subplots at each location. Main blocks were the two tillage treatments and subplots were 12 combinations of crop rotation and $\mathrm{P}$ fertilizer treatments. Tillage blocks were initiated in the first year of the study and continued until the completion of the study. The RT consisted of only fertilizer banding and seeding operations and the CT received two tillage passes in the fall and one pass in the spring with a cultivator equipped with tine harrows. The preceding crops were established on a different area within the tillage blocks each year. Registered herbicides were applied as required and according to recommendations of the Manitoba Guild to Crop Protection.
TABLE 2: Description of the experimental design in the study.

\begin{tabular}{lccc}
\hline Treatments & \multicolumn{3}{c}{ Phases } \\
& 1st & 2nd & 3rd \\
\hline Tillage & CT & CT & CT \\
& ZT & ZT & ZT \\
Crop rotation & Spring wheat & Flax & Durum wheat \\
& Canola & Flax & Durum wheat \\
P fertilization & 0 & 0 & 25 \\
$\left(\right.$ kg MAP ha $\left.^{-1}\right)$ & 0 & 25 & 0 \\
& 25 & 0 & 25 \\
& 25 & 25 & 0 \\
& 50 & 0 & 25 \\
& 50 & 25 & 0 \\
\hline
\end{tabular}

2.2. Sampling and Analysis. Prior to seeding of the durum wheat, $0-15 \mathrm{~cm}$ depth soil core samples were collected in each plot. Soil samples were air-dried and sieved. Available $\mathrm{P}$ was extracted from the soil with $0.5 \mathrm{~mol} \mathrm{~L}^{-1} \mathrm{NaHCO}_{3}$ [33]. Cadmium and $\mathrm{Zn}$ were extracted using DTPA [34]. Soil $\mathrm{pH}$ and EC were determined by a glass electrode using a 1:2 soil: water ratio. Concentrations of $\mathrm{P}$ and $\mathrm{Zn}$ in the extract were measured with an ARL 3410 ICP unit, and Cd on a Varian 300/400 atomic absorption spectrophotometer at a wavelength of $228.8 \mathrm{~nm}$ using a graphite furnace with

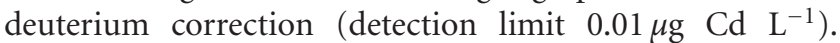
Reliability of the analysis was assessed by including certified soil reference materials and repeated samples in each set of soil extracts. Measured concentrations matched the stated ranges in the standards.

At crop maturity, grain yield of durum wheat was measured by harvesting the center four rows of the plot using a plot combine. Grain was dried at $30^{\circ} \mathrm{C}$ to a constant moisture 
level and the weight recorded for each plot. Grain samples were ground and digested with a boiling acid mixture $\left(\mathrm{HNO}_{3}+\mathrm{HClO}_{4}\right)$ for $\mathrm{Cd}$ and $\mathrm{Zn} \mathrm{[35].} \mathrm{The} \mathrm{concentrations}$ of $\mathrm{Zn}$ in the digest were determined on an ARL 3520 inductively coupled plasma (ICP) and Cd concentrations were determined on a Varian 300/400 atomic absorption spectrophotometer (AAS) at a wavelength of $228.8 \mathrm{~nm}$ using a graphite furnace with deuterium correction (detection limit $0.01 \mu \mathrm{g} \mathrm{Cd} \mathrm{L}^{-1}$ ). The reliability of the analysis was assessed by including certified plant reference materials and duplicate samples in each set of digests.

2.3. Statistical Analysis. Analysis of variance (Proc Mixed of SAS) was conducted on data separated by site-year. All interactions among fixed effect variables (tillage, crop rotation and $\mathrm{P}$ fertilization) were tested in the models and results showed that all interactions for grain yield and grain concentrations of elements were not significant. Therefore, only main effects of treatments were presented in this study. Means of the treatments were compared using protected least significance difference (LSD) at the 5\% level of probability. Relationships between parameters were determined using linear regression analysis. Principal component analysis (PCA) was used to describe relationships among variables and was performed using the correlation matrix method. Loading plots were generated using principal components 1 and 2 as axes, and variables were plotted along the axes. PCA was conducted with Minitab Statistical Software (Minitab 15) and other analyses were performed with SAS program, release 9.1 (SAS Institute Inc., Cary, USA).

\section{Results}

3.1. Grain Yield. Grain yield was greater with RT than CT in 3 site-years and less in 1 site-year (Table 3 ). Crop rotation and $\mathrm{P}$ fertilization, however, had little effect on grain yield. Grain yield was greater when canola-flax rather than wheatflax were the preceding crops in only one of 6 site-years, being BRC-North site in 2002. Differences in grain yield were only observed among $P$ treatments at MZTRF in 2002. There was no significant interaction among the treatments in their effect on grain yield.

3.2. Grain Cd Concentration and Accumulation. Grain Cd concentration ranged from 66.6 to $150.4 \mu \mathrm{g} \mathrm{kg}-1$ dry weight ( 56.6 to $127.5 \mu \mathrm{g} \mathrm{kg}^{-1}$ fresh weight based on approximately $15 \%$ water content). Grain Cd was less with RT than CT in 3 site-years and greater in 1 site-year (Table 4). Accumulation of Cd in the grain was also less with RT in 2 of 6 site-years and greater in 1 site-year. Effects of crop rotation and $\mathrm{P}$ fertilizer on grain $\mathrm{Cd}$ concentration and accumulation were insignificant in all but one site-year, being MZTRF-2001, where grain $\mathrm{Cd}$ concentration and accumulation was greater when following canola-flax than wheat-flax. Accumulation of Cd was increased by P fertilizer only at MZTRF in 2002, and was not affected in other site-years. There was no significant interaction among the treatments in their effect on Cd concentration and accumulation in the grain.
3.3. Grain $\mathrm{Zn}$ Concentration and Accumulation. Grain $\mathrm{Zn}$ concentration ranged from 23.0 to $42.3 \mathrm{mg} \mathrm{kg}^{-1}$ dry weight. Grain $\mathrm{Zn}$ concentration was higher with RT than CT in 3 of 6 site-years (Table 5). Compared to CT, RT increased grain $\mathrm{Zn}$ accumulation in 2001 and 2003, but decreased it in 2002 on BRC-North site. In contrast, grain $\mathrm{Zn}$ accumulation was not affected by tillage management on MZTRF site. Grain $\mathrm{Zn}$ concentration and accumulation in durum wheat was higher when following wheat-flax than canola-flax only at MZTRF site in 2003, and was not affected in other siteyears. Application of $\mathrm{P}$ fertilizer to either the previous crop or the current durum wheat crop did not affect grain $\mathrm{Zn}$ concentration. With increased application rate, however, grain $\mathrm{Zn}$ concentration showed a significantly decreasing trend in 2 of 6 site-years. Accumulation of $\mathrm{Zn}$ was not affected by $\mathrm{P}$ management in any site-years. Similar to Cd, grain $\mathrm{Zn}$ concentration and accumulation was not affected by any interactions among the treatments.

3.4. Correlation Analysis. Correlation analysis (Table 6) showed that grain $\mathrm{Cd}$ was positively correlated with grain $\mathrm{Fe}, \mathrm{P}, \mathrm{K}, \mathrm{Mg}$, and negatively correlated with grain $\mathrm{Mn}$, $\mathrm{Cu}$, and $\mathrm{Ca}$. A slightly negative but significant relationship was observed between yield and grain Cd $(r=-0.135$, $P<0.001)$. Both grain $\mathrm{Fe}$ and $\mathrm{Zn}$ were highly significantly positively correlated $(P<0.001)$ with other elements including $\mathrm{Mn}, \mathrm{P}, \mathrm{Ca}, \mathrm{K}$, and $\mathrm{Mg}$ and with protein content. Grain Fe, but not $\mathrm{Zn}$, was negatively correlated with grain yield and positively correlated with grain $\mathrm{Cd}$. Grain Fe and $\mathrm{Zn}$ were also positively correlated. Grain P was positively correlated with other measured element concentrations and negatively correlated with grain yield. The full dataset used for correlation matrix analysis is presented in Supplementary Table 1 (available online at doi:10.1155/2012/817107).

Grain concentrations of $\mathrm{Cd}, \mathrm{Zn}$ and $\mathrm{P}$ across site-years correlated significantly and positively with their extractable concentrations in soils (Table 6). Durum grain Cd was significantly related to soil extractable Cd concentration $(r=$ $0.339, P<0.001)$, as well as to soil extractable P concentration $(r=0.309, P<0.001)$. Grain concentrations of $\mathrm{Zn}, \mathrm{Fe}$, and $\mathrm{P}$, but not $\mathrm{Cd}$, were negatively related with soil $\mathrm{pH}$.

PCA of the dataset across 6 site-years extracted two major principal components, explaining $78 \%$ of the total variation in data (Figure 1). PC1 explained $54.4 \%$ of the variation, and was loaded positively with grain $\mathrm{Zn}, \mathrm{Mn}, \mathrm{P}, \mathrm{K}, \mathrm{Mg}, \mathrm{Fe}$, and soil $\mathrm{P}$, and negatively with grain yield and soil Cd. PC2 explained $23.6 \%$ of the variation, and was loaded positively with grain $\mathrm{Ca}$ and negatively with grain $\mathrm{Cd}$ and $\mathrm{Cu}$. The PCA showed strong associations between grain protein and grain concentrations of minerals such as $\mathrm{Zn}, \mathrm{Mn}, \mathrm{P}, \mathrm{K}, \mathrm{Mg}$, and Fe. In the biplot, the long and outside-scattered distribution of the six site-year vectors indicated that the environments were likely to have a great influence on the measured parameters. Grain Cd concentration was greatest in BRC-2003 and least in MZTRF-2002. In contrast, grain $\mathrm{Zn}$ concentration on either site was generally greater in 2001 than in other years. The least grain yield was recorded in BRC-2001 even though the soil had a relatively high $\mathrm{P}$ availability. 
TABLE 3: Grain yield $\left(\mathrm{kg} \mathrm{ha}^{-1}\right)$ of durum wheat as affected by tillage system, crop rotation, and P fertilization on at two sites over 3 years.

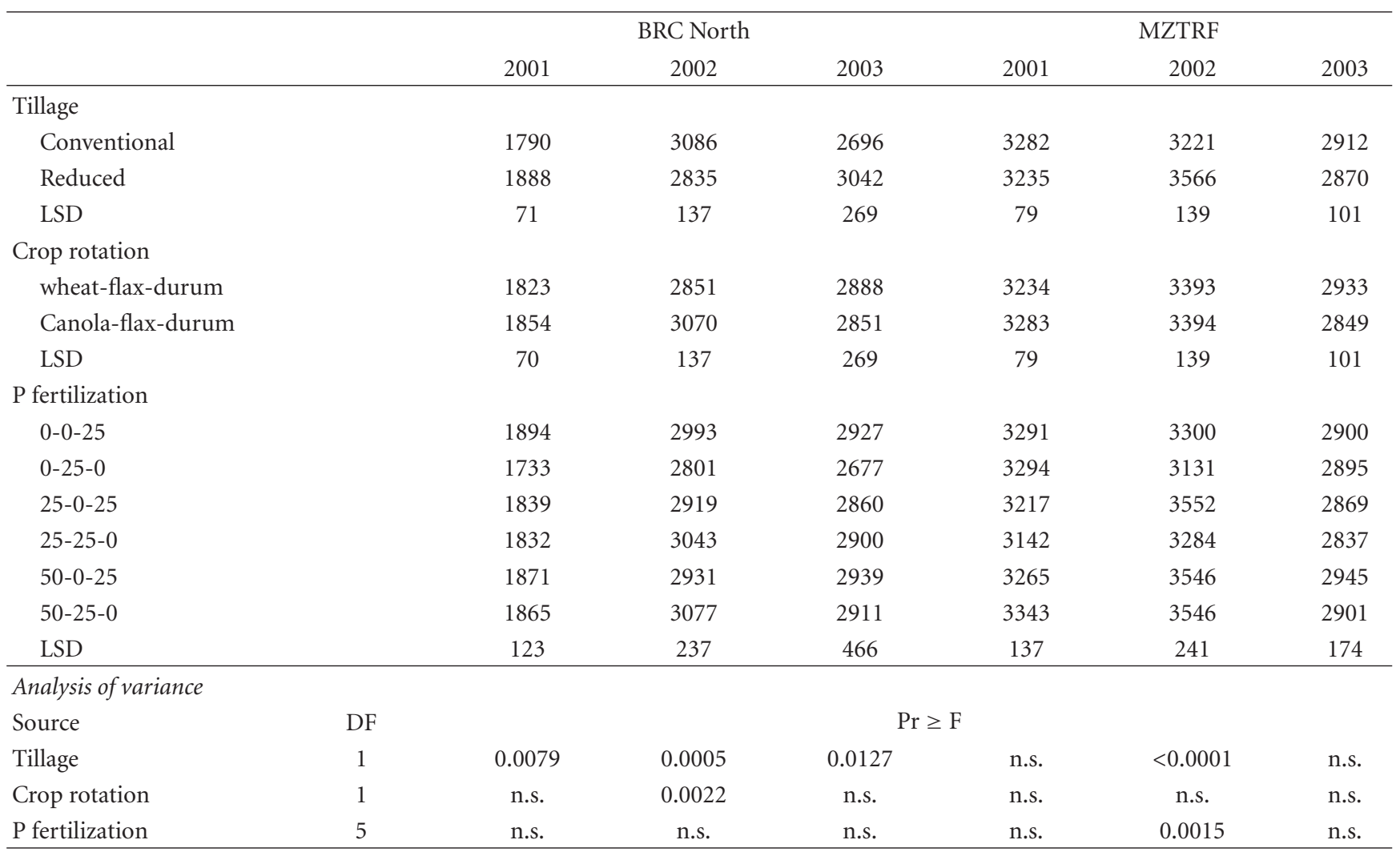

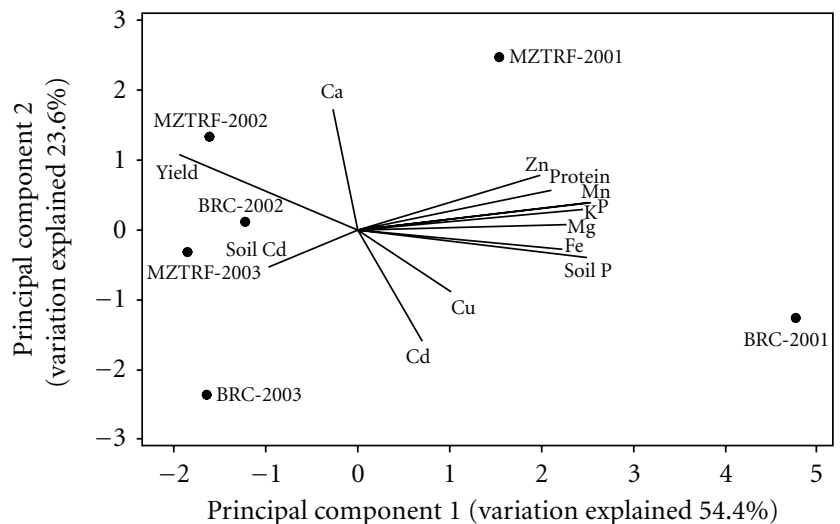

Figure 1: Principal component analysis (based on correlation matrix) of grain yield, grain concentrations of $\mathrm{Cd}, \mathrm{Zn}, \mathrm{Cu}, \mathrm{Fe}, \mathrm{Mg}, \mathrm{K}$, $\mathrm{P}, \mathrm{Mn}, \mathrm{Ca}$, grain protein concentration, and selected soil properties (soil $\mathrm{P}$ and soil Cd) across 6 site-years. Biplot vectors are trait factor loadings for principal component 1 (PC1) and PC2. Data at each site-year are averaged across $\mathrm{P}$ fertilizer treatments.

\section{Discussion}

Grain yield was relatively low at the BRC-North site in 2001 (Table 3, Figure 1), due to adverse weather conditions, but was average for the area in the other site-years. The range of $\mathrm{Cd}$ concentrations in durum grain in this study was also within the expected range, being comparable to that reported in our previous studies on the Canadian prairies [31, 36], and well below the proposed Codex maximum limit in wheat grain [3]. This suggests the durum wheat production in the area is generally safe for human consumption. However, $\mathrm{Zn}$ concentrations in the grain were generally less than the biofortification target of $40-60 \mathrm{mg}$ $\mathrm{kg}^{-1}$, which is required to counteract human $\mathrm{Zn}$ deficiency in many parts of the world [37]. Therefore, it is desirable to increase $\mathrm{Zn}$ concentration in durum grain, either by genetic improvement or agricultural practices.

Of the factors evaluated, tillage management showed the greatest influence on grain yield, as well as on grain $\mathrm{Cd}$ and $\mathrm{Zn}$ concentrations and accumulations in durum wheat. Compared to CT, RT significantly increased grain yield and $\mathrm{Zn}$, and decreased grain $\mathrm{Cd}$ in half of the site-years (Tables $3,4,5)$. The decrease in $\mathrm{Cd}$, however, was neither necessarily related to the increase in $\mathrm{Zn}$, nor to the increase in grain yield, as suggested by the nonrelationship or weak relationship among these three variables (Table 6). It should be noted that the observed effects of tillage on grain $\mathrm{Cd}$ and $\mathrm{Zn}$ were not expected because our previous studies suggested that tillage system had very limited influence on either Cd [29] or $\mathrm{Zn}$ [38] concentrations in durum grain. Also, in the second phase of the current study where the flax was the tested crop, tillage management also did not exert any consistent effect on flaxseed concentrations of $\mathrm{Cd}$ and $\mathrm{Zn}$ [25]. It is unclear why there was an effect of tillage in this growing season 
TABLE 4: Grain Cd concentration $\left(\mu \mathrm{g} \mathrm{kg}^{-1}\right)$ and accumulation $\left(\mathrm{mg} \mathrm{ha}^{-1}\right)$ of durum wheat as affected by tillage system, crop rotation, and $\mathrm{P}$ fertilization on at two sites over 3 years.

\begin{tabular}{|c|c|c|c|c|c|c|c|c|c|c|c|c|c|}
\hline & & \multicolumn{5}{|c|}{ Grain Cd concentration $\left(\mu \mathrm{g} \mathrm{kg}^{-1}\right)$} & \multicolumn{6}{|c|}{ Grain Cd accumulation $\left(\mathrm{mg} \mathrm{ha}^{-1}\right)$} & \\
\hline & & \multicolumn{3}{|c|}{ BRC North } & \multicolumn{2}{|c|}{ MZTRF } & \multicolumn{4}{|c|}{ BRC North } & \multicolumn{3}{|c|}{ MZTRF } \\
\hline & & 2001 & 2002 & 2003 & 2001 & 2002 & 2003 & 2001 & 2002 & 2003 & 2001 & 2002 & 2003 \\
\hline \multicolumn{14}{|l|}{ Tillage } \\
\hline Conventional & & 120.1 & 122.8 & 144.2 & 82.5 & 86.1 & 83.5 & 216 & 380 & 401 & 269 & 279 & 247 \\
\hline Reduced & & 120.4 & 70.1 & 119.8 & 81.8 & 61.3 & 99.8 & 228 & 205 & 380 & 267 & 221 & 289 \\
\hline LSD & & 9.1 & 13.9 & 15.9 & 4.8 & 8.7 & 11.3 & 20 & 48 & 80 & 18 & 31 & 37 \\
\hline \multicolumn{14}{|l|}{ Crop rotation } \\
\hline wheat-flax-durum & & 117.3 & 92.0 & 131.1 & 78.6 & 70.5 & 90.8 & 215 & 270 & 394 & 255 & 239 & 270 \\
\hline Canola-flax-durum & & 123.3 & 100.9 & 132.9 & 85.6 & 76.9 & 92.5 & 229 & 316 & 387 & 282 & 260 & 266 \\
\hline LSD & & 9.1 & 13.9 & 15.9 & 4.8 & 8.7 & 11.3 & 20 & 48 & 80 & 18 & 31 & 37 \\
\hline \multicolumn{14}{|l|}{ P fertilization } \\
\hline $0-0-25$ & & 117.1 & 89.9 & 132.2 & 83.1 & 68.4 & 88.6 & 223 & 272 & 400 & 274 & 226 & 258 \\
\hline $0-25-0$ & & 110.3 & 97.5 & 116.2 & 80.3 & 72.9 & 87.9 & 191 & 287 & 318 & 265 & 226 & 257 \\
\hline $25-0-25$ & & 116.9 & 94.8 & 133.9 & 82.3 & 81.8 & 94.6 & 216 & 283 & 393 & 265 & 291 & 277 \\
\hline $25-25-0$ & & 120.7 & 98.9 & 126.0 & 78.5 & 68.3 & 83.1 & 223 & 307 & 369 & 248 & 226 & 239 \\
\hline $50-0-25$ & & 131.1 & 99.7 & 150.4 & 87.1 & 84.3 & 111.1 & 244 & 304 & 459 & 285 & 295 & 329 \\
\hline $50-25-0$ & & 125.5 & 97.8 & 133.2 & 81.5 & 66.6 & 84.6 & 234 & 302 & 404 & 272 & 237 & 247 \\
\hline LSD & & 15.7 & 24.1 & 27.5 & 8.3 & 15.1 & 19.5 & 35 & 84 & 139 & 32 & 54 & 64 \\
\hline \multicolumn{14}{|l|}{ Analysis of variance } \\
\hline Source & DF & & & & & & $\operatorname{Pr} \geq F$ & & & & & & \\
\hline Tillage & 1 & n.s. & $<0.001$ & 0.003 & n.s. & $<0.001$ & 0.005 & n.s. & $<0.001$ & n.s. & n.s. & 0.004 & 0.025 \\
\hline Crop rotation & 1 & n.s. & n.s. & n.s. & 0.005 & n.s. & n.s. & n.s. & n.s. & n.s. & 0.005 & n.s. & n.s. \\
\hline P fertilization & 5 & n.s. & n.s. & n.s. & n.s. & n.s. & n.s. & n.s. & n.s. & n.s. & n.s. & 0.014 & n.s. \\
\hline
\end{tabular}

but not in the previous seasons. Some studies suggested that tillage management can have an impact on metal availability in soils by its influence on soil properties such as $\mathrm{pH}$, organic carbon content and cation exchange capacity [29, 39]. This assumption, however, is not supported in this stud$\mathrm{y}$ because soil concentrations of extractable $\mathrm{Cd}$ and $\mathrm{Zn}$ were not consistently affected by tillage management (data not present). Instead, the difference in mycorrhizal association could play a role. Compared to RT, annual soil disturbances produced by CT may reduce mycorrhizal colonization in crops [40] and thus influence root uptake of Cd [41] or $\mathrm{Zn}$ [42]. In addition, tillage effects may vary from year to year because of differences in weather conditions. Under prairie conditions, RT tends to have greater benefits under warmer, drier conditions where moisture conservation become important. Similarly, seasonal differences in weather may interact with tillage effects on both root distribution in different soil layers and rate of decomposition of crop residues, to influence metal uptake. While the impact of tillage is not consistent across different studies on the Canadian prairies $[25,31,32,36]$, the RT practices may be beneficial to farmers in many regions not only because of the benefits in conserving soil moisture, preventing soil erosion and reducing the cost of production [26], but also for potential improvements in grain yield and grain quality, as has been shown in the current study.
There was no consistent difference in grain yield or grain concentration of $\mathrm{Cd}$ or $\mathrm{Zn}$ between durum wheat following spring wheat-flax as compared to canola-flax. In contrast, in the second phase of this study, flaxseed following canola had significantly higher Cd concentration and lower $\mathrm{Zn}$ concentration than following spring wheat [25]. These results suggest that the impact of spring wheat or canola as a preceding crop was significant only on the following crop, and did not persist to affect the third crop in the sequence. Potential mechanisms explaining preceding crop effect on flax were discussed in Grant et al. [25], including difference in $\mathrm{Cd}$ and $\mathrm{Zn}$ content in the crop residue which was returned to the soil after harvest, difference in mycorrhizal association between mycorrhizal spring wheat and nonmycorrhizal canola, as well as difference in root-induced rhizosphere chemical changes between canola and wheat.

In spite of the low initial soil $\mathrm{P}$ concentration at the two locations, there was no statistically significant main effect on grain yield from the different amounts or timings of $\mathrm{P}$ fertilization through the three-year cropping sequence (Table $3)$. However, in 4 of 6 site-years, there was a statistical or numerical advantage from 160 to $250 \mathrm{~kg} \mathrm{ha}^{-1}$ of grain yield with application of the $\mathrm{P}$ to the durum wheat rather than in the preceding crop at the lowest rate of application (Table 3 ), a difference that was significant at the $P<0.02-0.28$ rate using contrast analysis (data not present). This differential 
TABLE 5: Grain Zn concentration $\left(\mathrm{mg} \mathrm{kg}^{-1}\right)$ and accumulation $\left(\mathrm{g} \mathrm{ha}^{-1}\right)$ of durum wheat as affected by tillage system, crop rotation, and $\mathrm{P}$ fertilization on at two sites over 3 years.

\begin{tabular}{|c|c|c|c|c|c|c|c|c|c|c|c|c|c|}
\hline & & \multicolumn{5}{|c|}{ Grain $\mathrm{Zn}$ concentration $\left(\mathrm{mg} \mathrm{kg}^{-1}\right)$} & \multicolumn{6}{|c|}{ Grain $\mathrm{Zn}$ accumulation $\left(\mathrm{g} \mathrm{ha}^{-1}\right)$} & \\
\hline & & \multicolumn{3}{|c|}{ BRC-North } & \multicolumn{3}{|c|}{ MZTRF } & \multicolumn{3}{|c|}{ BRC-North } & \multicolumn{3}{|c|}{ MZTRF } \\
\hline & & 2001 & 2002 & 2003 & 2001 & 2002 & 2003 & 2001 & 2002 & 2003 & 2001 & 2002 & 2003 \\
\hline \multicolumn{14}{|l|}{ Tillage } \\
\hline Conventional & & 38.0 & 26.6 & 23.7 & 35.6 & 37.0 & 25.3 & 68.2 & 82.4 & 65.9 & 116.9 & 119.3 & 74.6 \\
\hline Reduced & & 40.1 & 26.0 & 26.3 & 37.4 & 35.6 & 24.9 & 75.5 & 74.2 & 82.9 & 120.9 & 126.6 & 72.1 \\
\hline LSD & & 1.9 & 1.3 & 2.5 & 1.8 & 2.3 & 1.5 & 4.7 & 6.5 & 13.9 & 5.9 & 8.9 & 6.4 \\
\hline \multicolumn{14}{|l|}{ Crop rotation } \\
\hline wheat-flax-durum & & 39.5 & 26.2 & 25.7 & 36.9 & 36.2 & 26.1 & 72.0 & 74.9 & 77.1 & 119.6 & 123.1 & 77.3 \\
\hline Canola-flax-durum & & 38.7 & 26.5 & 24.3 & 36.1 & 36.4 & 24.1 & 71.7 & 81.7 & 71.7 & 118.3 & 122.8 & 69.3 \\
\hline LSD & & 1.9 & 1.3 & 2.5 & 1.8 & 2.3 & 1.5 & 4.7 & 6.5 & 13.9 & 5.9 & 8.9 & 6.4 \\
\hline \multicolumn{14}{|l|}{ P fertilization } \\
\hline $0-0-25$ & & 37.9 & 27.4 & 24.9 & 38.0 & 35.7 & 25.6 & 71.9 & 82.3 & 76.1 & 125.1 & 118.1 & 74.8 \\
\hline $0-25-0$ & & 42.3 & 27.4 & 26.5 & 37.4 & 38.7 & 27.4 & 73.2 & 77.6 & 73.4 & 123.0 & 121.0 & 80.6 \\
\hline $25-0-25$ & & 39.8 & 25.6 & 23.7 & 37.1 & 34.9 & 23.8 & 72.8 & 74.7 & 71.1 & 119.4 & 124.1 & 69.3 \\
\hline $25-25-0$ & & 39.4 & 26.9 & 26.7 & 35.7 & 37.0 & 26.1 & 72.2 & 82.9 & 79.3 & 112.0 & 122.5 & 74.7 \\
\hline $50-0-25$ & & 37.9 & 25.0 & 23.4 & 35.7 & 34.3 & 23.0 & 71.4 & 73.5 & 71.8 & 116.5 & 121.1 & 68.4 \\
\hline $50-25-0$ & & 37.3 & 25.6 & 24.8 & 35.2 & 37.0 & 24.6 & 69.5 & 78.8 & 74.8 & 117.6 & 130.7 & 72.1 \\
\hline LSD & & 3.3 & 2.2 & 4.3 & 3.1 & 4.1 & 2.6 & 8.2 & 11.3 & 24.1 & 10.3 & 15.4 & 11.2 \\
\hline \multicolumn{14}{|l|}{ Analysis of variance } \\
\hline Source & DF & & & & & & $\operatorname{Pr} \geq F$ & & & & & & \\
\hline Tillage & 1 & 0.036 & n.s. & 0.034 & 0.043 & n.s. & n.s. & 0.003 & 0.014 & 0.018 & n.s. & n.s. & n.s. \\
\hline Crop rotation & 1 & n.s. & n.s. & n.s. & n.s. & n.s. & 0.013 & n.s. & 0.042 & n.s. & n.s. & n.s. & 0.015 \\
\hline $\mathrm{P}$ fertilization & 5 & 0.034 & n.s. & n.s. & n.s. & n.s. & 0.015 & n.s. & n.s. & n.s. & n.s. & n.s. & n.s. \\
\hline
\end{tabular}

was much lower or nonexistent when higher amounts of $\mathrm{P}$ were applied through the cropping sequence. It appears that if the level of input through the cropping sequence is low, there may be a small yield advantage to providing some $\mathrm{P}$ as a starter near the seed row in the current crop. The benefit of the use of starter $\mathrm{P}$ diminishes as the $\mathrm{P}$ input through the rotation decreases.

In other field studies, that is, in Sweden [43] and in the Canadian prairies [13], Cd concentration in grain and seed of several crops consistently increased with increasing $\mathrm{P}$ application, which was attributed to either the direct addition of the Cd contained in the fertilizer or the indirect effect on soil chemical properties. The MAP used in this study,

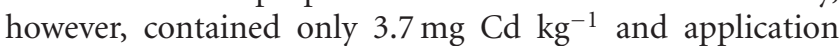
of $75 \mathrm{~kg}$ fertilizer over 3 growing seasons would add only $278 \mathrm{mg}$ of $\mathrm{Cd}$ to the soil per hectare, making it unlikely to have a strong effect on Cd concentration in crop grain. Similarly, in studies in the USA, long-term application of fertilizers containing less than $5 \mathrm{mg} \mathrm{Cd} \mathrm{kg}{ }^{-1}$ did not increase $\mathrm{Cd}$ concentration in soil and crops [44]. In 2 of 6 site-years, $\mathrm{P}$ fertilizer treatment exerted a significant effect on grain $\mathrm{Zn}$ concentration, with the trend being that grain $\mathrm{Zn}$ decreased with increased application rate over the three growing seasons (Table 5). Similarly, in the second phase of this study, seed $\mathrm{Zn}$ concentration of flax decreased with application of $\mathrm{P}$ in half of the site-years [25]. The P-induced inhibition of $\mathrm{Zn}$ accumulation is frequently reported and may be related to the P-Zn interaction in soil [14] and depression in mycorrhizal association caused by increased P supply [45].

The impacts of the agricultural management on grain yield and grain quality were highly unstable. Their performance varied across locations and years. For example, the reduced tillage significantly improved grain yield and grain quality as compared to the conventional tillage in half of the site-years. The effect, however, was absent or even opposite in other site-years. Also, increasing P fertilizer rate decreased grain $\mathrm{Zn}$ in 2 site-years, but not in the others. Therefore, the environmental conditions such as location or meteorological factors are important determinants for agronomic and nutrient traits. This assumption is also confirmed by the wide range of the site-year criteria in the PCA biplot (Figure 1). Still, only one wheat genotype was tested in the current study, neglecting the potential genotype by environment interactions, as been shown in other studies concerning grain $\mathrm{Cd}$ [46] and grain $\mathrm{Zn} \mathrm{[47].} \mathrm{Hence,} \mathrm{greater} \mathrm{efforts} \mathrm{taking} \mathrm{care}$ of genotype by environment interactions are needed to produce improved grain quality for human health.

Results of the linear regression and PCA showed grain Zn concentration was correlated positively to other nutrients such as $\mathrm{Fe}, \mathrm{Mn}, \mathrm{P}, \mathrm{Ca}, \mathrm{K}$, and $\mathrm{Mg}$, but was not correlated to grain Cd (Table 6, Figure 1). The relationships favor the possibility of producing durum grain with moderately high nutrients, while maintaining low concentration of Cd. Also, both grain $\mathrm{Zn}$ and Fe concentrations correlated positively 
TABLE 6: Correlation coefficients $(r)$ of grain concentrations of Cd, $\mathrm{Zn}, \mathrm{Fe}$ and $\mathrm{P}$ to other elements concentrations, grain yield, grain protein concentration, and soil characteristics (The full dataset is presented in Supplementary Table 1).

\begin{tabular}{|c|c|c|c|c|}
\hline & $\mathrm{Cd}$ & $\mathrm{Zn}$ & $\mathrm{Fe}$ & $\mathrm{P}$ \\
\hline \multicolumn{5}{|l|}{ Grain } \\
\hline $\mathrm{Zn}$ & -0.022 & - & $0.507^{* * *}$ & $0.688^{* * *}$ \\
\hline $\mathrm{Fe}$ & $0.294^{* * *}$ & $0.507 * * *$ & - & $0.598^{* * *}$ \\
\hline Mn & $-0.150^{* * *}$ & $0.239^{* * *}$ & $0.441^{* * *}$ & $0.504^{* * *}$ \\
\hline $\mathrm{Cu}$ & $-0.134^{* * *}$ & $0.096^{*}$ & 0.067 & $0.101^{*}$ \\
\hline $\mathrm{P}$ & $0.223^{* * *}$ & $0.688^{* * *}$ & $0.598^{* * *}$ & - \\
\hline $\mathrm{Ca}$ & $-0.365^{* * *}$ & $0.408^{* * *}$ & -0.017 & $0.168^{* * *}$ \\
\hline $\mathrm{K}$ & $0.081^{*}$ & $0.755^{* * *}$ & $0.579^{* * *}$ & $0.833^{* * *}$ \\
\hline $\mathrm{Mg}$ & $0.191^{* * *}$ & $0.491^{* * *}$ & $0.390^{* * *}$ & $0.691^{* * *}$ \\
\hline Protein & 0.036 & $0.425^{* * *}$ & $0.529^{* * *}$ & $0.636^{* * *}$ \\
\hline Yield & $-0.135^{* * *}$ & -0.014 & $-0.302^{* * *}$ & $-0.292^{* * *}$ \\
\hline \multicolumn{5}{|l|}{ Soil } \\
\hline $\mathrm{pH}$ & -0.080 & $-0.635^{* * *}$ & $-0.193^{* *}$ & $-0.255^{* * *}$ \\
\hline $\mathrm{EC}$ & -0.094 & -0.047 & -0.041 & -0.095 \\
\hline Olsen-P & $0.309^{* * *}$ & $0.324^{* * *}$ & $0.537 * * *$ & $0.553^{* * *}$ \\
\hline DTPA-Cd & $0.339^{* * *}$ & $0.213^{* * *}$ & $0.235^{* * *}$ & 0.012 \\
\hline DTPA-Zn & 0.044 & $0.523^{* * *}$ & $0.193^{* * *}$ & $0.201^{* *}$ \\
\hline
\end{tabular}

with grain protein content. This finding is consistent with other field trials [48] and suggested a possible link between grain protein and the levels of the two micronutrients.

\section{Conclusions}

In summary, of the factors evaluated, tillage had the most consistent effect on grain concentrations of $\mathrm{Cd}$ and $\mathrm{Zn}$. Compared to CT, RT increased grain yield, grain $\mathrm{Zn}$, and decreased grain $\mathrm{Cd}$ in half of the site-years and should therefore be recommended in tested area. The effect of growing wheat rather than canola as a preceding crop on crop yield or trace element concentration did not persist to affect durum wheat grown as the third crop in the sequence. There was evidence of a small impact of starter $\mathrm{P}$ on grain yield, but only if the levels of $\mathrm{P}$ applied through the cropping sequence were low, indicating that $\mathrm{P}$ fertilizer applied in preceding years can remain plant-available, reducing the requirements for $\mathrm{P}$ input in following crops. Rate and timing of $\mathrm{P}$ application had little effect on grain concentration of $\mathrm{Cd}$, but increasing $\mathrm{P}$ rate tended to decrease grain $\mathrm{Zn}$ concentration. The linear and multivariate regressions revealed that grain $\mathrm{Zn}$ was not related to grain $\mathrm{Cd}$, but was positively correlated with other nutrients such as $\mathrm{Fe}, \mathrm{Mn}, \mathrm{P}, \mathrm{Ca}, \mathrm{K}$, and $\mathrm{Mg}$, suggesting the possibility of producing durum grain with moderately high nutrients, while maintaining low concentration of Cd. Grain protein may represent a sink for micronutrients such as $\mathrm{Zn}$ and Fe. No interactive effect was detected among tested factors. Results of the study suggest that tillage management can have persistent effects on both grain yield and quality, that impacts of preceding crop do not persist past the first subsequent season and that $\mathrm{P}$ fertilizer can remain available for subsequent crops, reducing the response to annual inputs if $\mathrm{P}$ levels are maintained at adequate levels throughout the cropping sequence.

\section{Acknowledgments}

The authors gratefully acknowledge the financial support of Saskatchewan Flax Commission, International Plant Nutrition Institute, Westco Fertilizers, Ltd., Agrium, Ltd., United Grain Growers, and the Matching Investment Initiative of Agriculture and Agri-Food Canada for funding the study. The technical assistance of Brian Hadley, Mike Svistovski, Kim McDonald, and David Bancur is greatly appreciated.

\section{References}

[1] Jansson G., Cadmium in arable crops: the influence of soil factors and liming, Ph.D. thesis, Department of Soil Sciences, The Swedish University of Agricultural Sciences, Uppsala Sweden, 2002.

[2] C. A. Grant and L. D. Bailey, "Nitrogen, phosphorus and zinc management effects on grain yield and cadmium concentration in two cultivars of durum wheat," Canadian Journal of Plant Science, vol. 78, no. 1, pp. 63-70, 1998.

[3] "Codex general standard for contaminants and toxins in foods," CODEX STAN 193-1995, Rev. 5, 2009.

[4] Canada Statistics, "Crops and horticulture," 2010, http:// www40.statcan.gc.ca/101/ind01/13_920_2024-eng.htm?hili_ none.

[5] C. A. Grant, W. T. Buckley, L. D. Bailey, and F. Selles, "Cadmium accumulation in crops," Canadian Journal of Plant Science, vol. 78, no. 1, pp. 1-17, 1998.

[6] J. M. Clarke, D. Leisle, R. A. DePauw, and L. L. Thiessen, "Registration of five pairs of durum wheat genetic stocks nearisogenic for cadmium concentration," Crop Science, vol. 37, no. 1, p. 297, 1997.

[7] M. J. McLaughlin, D. R. Parker, and J. M. Clarke, "Metals and micronutrients: food safety issues," Field Crops Research, vol. 60, no. 1-2, pp. 143-163, 1999.

[8] I. Cakmak, W. H. Pfeiffer, and B. McClafferty, "Biofortification of durum wheat with zinc and iron," Cereal Chemistry, vol. 87, no. 1, pp. 10-20, 2010.

[9] E. J. Gawalko, R. G. Garrett, and T. W. Nowicki, "Cadmium, copper, iron, manganese, selenium, and zinc in Canadian spring wheat," Communications in Soil Science and Plant Analysis, vol. 33, no. 15-18, pp. 3121-3133, 2002.

[10] C. A. Grant and S. C. Sheppard, "Fertilizer impacts on cadmium availability in agricultural soils and crops," Human and Ecological Risk Assessment, vol. 14, no. 2, pp. 210-228, 2008.

[11] K. C. Jones and A. E. Johnston, "Cadmium in cereal grain and herbage from long-term experimental plots at Rothamsted, UK," Environmental Pollution, vol. 57, no. 3, pp. 199-216, 1989.

[12] M. A. Kashem and B. R. Singh, "The effect of fertilizer additions on the solubility and plant-availability of $\mathrm{Cd}, \mathrm{Ni}$ and $\mathrm{Zn}$ in soil," Nutrient Cycling in Agroecosystems, vol. 62, no. 3, pp. 287-296, 2002.

[13] C. A. Grant and L. D. Bailey, "Effects of phosphorus and zinc fertiliser management on cadmium accumulation in flaxseed," Journal of the Science of Food and Agriculture, vol. 73, no. 3, pp. 307-314, 1997. 
[14] J. O. Agbenin, "Phosphate-induced zinc retention in a tropical semi-arid soil," European Journal of Soil Science, vol. 49, no. 4, pp. 693-700, 1998.

[15] T. S. Verma and R. S. Minhas, "Zinc and phosphorus interaction in a wheat-maize cropping system," Fertilizer Research, vol. 13, no. 1, pp. 77-86, 1987.

[16] M. Haldar and L. N. Mandal, "Effect of phosphorus and zinc on the growth and phosphorus, zinc, copper, iron and manganese nutrition of rice," Plant and Soil, vol. 59, no. 3, pp. 415425, 1981.

[17] S. R. Olsen, "Micronutrient interaction," in Micronutrients in Agriculture, J. J. Mortvedt, P. M. Giordano, and W. L. Lindsay, Eds., pp. 243-264, Soil Science Society of America, Wis, USA, 1972.

[18] X. Gao, D. N. Flaten, M. Tenuta, M. G. Grimmett, E. J. Gawalko, and C. A. Grant, "Soil solution dynamics and plant uptake of cadmium and zinc by durum wheat following phosphate fertilization," Plant and Soil, vol. 338, no. 1, pp. 423-434, 2011.

[19] M. Choudhary, L. D. Bailey, and C. A. Grant, "Effect of zinc on cadmium concentration in the tissue of durum wheat," $\mathrm{Ca}$ nadian Journal of Plant Science, vol. 74, no. 3, pp. 549-552, 1994.

[20] Y. Jiao, C. A. Grant, and L. D. Bailey, "Effects of phosphorus and zinc fertilizer on cadmium uptake and distribution in flax and durum wheat," Journal of the Science of Food and Agriculture, vol. 84, no. 8, pp. 777-785, 2004.

[21] P. R. Miller, Y. Gan, B. G. McConkey, and C. L. McDonald, "Pulse crops for the northern Great Plains: I. Grain productivity and residual effects on soil water and nitrogen," Agronomy Journal, vol. 95, no. 4, pp. 972-979, 2003.

[22] C. A. Campbell, R. P. Zentner, F. Selles et al., "Quantifying short-term effects of crop rotations on soil organic carbon in southwestern Saskatchewan," Canadian Journal of Soil Science, vol. 80, no. 1, pp. 193-202, 2000.

[23] C. Hamel, K. Hanson, F. Selles et al., "Seasonal and long-term resource-related variations in soil microbial communities in wheat-based rotations of the Canadian prairie," Soil Biology and Biochemistry, vol. 38, no. 8, pp. 2104-2116, 2006.

[24] D. P. Oliver, J. E. Schultz, K. G. Tiller, and R. H. Merry, “The effect of crop rotation and tillage practices on cadmium concentration in wheat grain," Australian Journal of Agricultural Research, vol. 44, no. 6, pp. 1221-1234, 1993.

[25] C. A. Grant, M. A. Monreal, R. B. Irvine, R. M. Mohr, D. L. McLaren, and M. Khakbazan, "Preceding crop and phosphorus fertilization affect cadmium and zinc concentration of flaxseed under conventional and reduced tillage," Plant and Soil, vol. 333, no. 1, pp. 337-350, 2010.

[26] R. P. Zentner, G. P. Lafond, D. A. Derksen, and C. A. Campbell, "Tillage method and crop diversification: effect on economic returns and riskiness of cropping systems in a thin black chernozem of the Canadian prairies," Soil and Tillage Research, vol. 67, no. 1, pp. 9-21, 2002.

[27] C. A. Grant and L. D. Bailey, "The effect of tillage and $\mathrm{KCl}$ addition on $\mathrm{pH}$, conductance, $\mathrm{NO}_{3}-\mathrm{N}, \mathrm{P}, \mathrm{K}$ and $\mathrm{Cl}$ distribution in the soil profile," Canadian Journal of Soil Science, vol. 74, no. 3, pp. 307-314, 1994.

[28] K. G. Tiller, D. P. Oliver, M. J. McLaughlin et al., "Managing cadmium contamination of agricultural land," in Remediation of Soils Contaminated by Metals, I. K. Iskandar, Ed., pp. 225255, Science and Technology Letters, Northwood, UK, 1997.

[29] A. J. Franzluebbers and F. M. Hons, "Soil-profile distribution of primary and secondary plant-available nutrients under con- ventional and no tillage," Soil and Tillage Research, vol. 39, no. 3-4, pp. 229-239, 1996.

[30] L. M. Shuman and D. V. McCracken, "Tillage, lime, and poultry litter effects on soil zinc, manganese, and copper," Communications in Soil Science and Plant Analysis, vol. 30, no. 9-10, pp. 1267-1277, 1999.

[31] X. Gao, F. Akhter, M. Tenuta, D. N. Flaten, E. J. Gawalko, and C. A. Grant, "Mycorrhizal colonization and grain Cd concentration of field-grown durum wheat in response to tillage, preceding crop and phosphorus fertilization," Journal of the Science of Food and Agriculture, vol. 90, no. 5, pp. 750-758, 2010.

[32] C. A. Grant, M. A. Monreal, R. B. Irvine, R. M. Mohr, D. L. Mclaren, and M. Khakbazan, "Crop response to current and previous season applications of phosphorus as affected by crop sequence and tillage," Canadian Journal of Plant Science, vol. 89, no. 1, pp. 49-66, 2009.

[33] S. R. Olsen, C. V. Cole, F. S. Watanabe, and L. A. Dean, "Estimation of available phosphorus in soils by extraction with sodium bicarbonate," Circular number 939, USDA, 1954.

[34] W. L. Lindsay and W. A. Norvell, "Development of a DTPA soil test for zinc, iron, manganese, and copper," Soil Science Society of America Journal, vol. 42, no. 4, pp. 421-428, 1978.

[35] R. L. Westerman, Soil Testing and Plant Analysis, Soil Science Society of America, Madison, Wis, USA, 1990.

[36] X. Gao, K. R. Brown, G. J. Racz, and C. A. Grant, "Concentration of cadmium in durum wheat as affected by time, source and placement of nitrogen fertilization under reduced and conventional-tillage management," Plant and Soil, vol. 337, no. 1, pp. 341-354, 2010.

[37] R. D. Graham, R. M. Welch, D. A. Saunders et al., "Nutritious subsistence food systems," Advances in Agronomy, vol. 92, pp. 1-74, 2007.

[38] X. Gao and C. A. Grant, "Interactive effect of N fertilization and tillage management on $\mathrm{Zn}$ biofortification in durum wheat (Triticum durum)," Canadian Journal of Plant Science, vol. 91, no. 6, pp. 951-960, 2011.

[39] K. R. J. Smettem, A. D. Rovira, S. A. Wace, B. R. Wilson, and A. Simon, "Effect of tillage and crop rotation on the surface stability and chemical properties of a red-brown earth (Alfisol) under wheat," Soil and Tillage Research, vol. 22, no. 1-2, pp. 27-40, 1992.

[40] C. G. Castillo, R. Rubio, J. L. Rouanet, and F. Borie, "Early effects of tillage and crop rotation on arbuscular mycorrhizal fungal propagules in an Ultisol," Biology and Fertility of Soils, vol. 43, no. 1, pp. 83-92, 2006.

[41] X. Gao, M. Tenuta, D. N. Flaten, and C. A. Grant, "Cadmium concentration in flax colonized by mycorrhizal fungi depends on soil phosphorus and cadmium concentrations," Communications in Soil Science and Plant Analysis, vol. 42, no. 15, pp. 1882-1897, 2011.

[42] M. H. Ryan, J. K. McInerney, I. R. Record, and J. F. Angus, "Zinc bioavailability in wheat grain in relation to phosphorus fertiliser, crop sequence and mycorrhizal fungi," Journal of the Science of Food and Agriculture, vol. 88, no. 7, pp. 1208-1216, 2008.

[43] A. Andersson and G. Simon, "Levels of Cd and some other trace elements in soils and crops as influenced by lime and fertilizer level," Acta Agriculturae Scandinavica, vol. 4l, pp. 311, 1991.

[44] J. J. Mortvedt, "Cadmium levels in soils and plants from some long-term soil fertility experiments in the United States of America," Journal of Environmental Quality, vol. 16, no. 2, pp. 137-142, 1987. 
[45] M. A. Monreal, C. A. Grant, R. B. Irvine, R. M. Mohr, D. L. McLaren, and M. Khakbazan, "Crop management effect on arbuscular mycorrhizae and root growth of flax," Canadian Journal of Plant Science, vol. 91, no. 2, pp. 315-324, 2011.

[46] X. Gao, R. M. Mohr, D. L. McLaren, and C. A. Grant, "Grain cadmium and zinc concentrations in wheat as affected by genotypic variation and potassium chloride fertilization," Field Crops Research, vol. 122, no. 2, pp. 95-103, 2011.

[47] A. K. Joshi, J. Crossa, B. Arun et al., "Genotype $\times$ environment interaction for zinc and iron concentration of wheat grain in eastern Gangetic plains of India," Field Crops Research, vol. 116, no. 3, pp. 268-277, 2010.

[48] F. J. Zhao, Y. H. Su, S. J. Dunham et al., "Variation in mineral micronutrient concentrations in grain of wheat lines of diverse origin," Journal of Cereal Science, vol. 49, no. 2, pp. 290-295, 2009. 

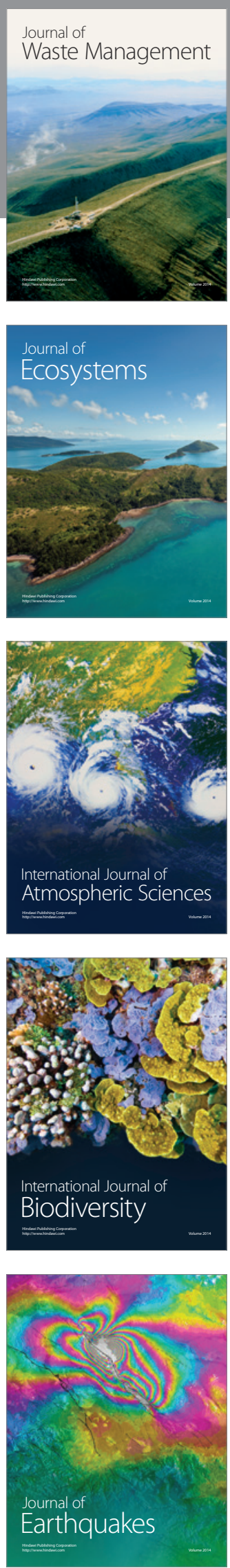
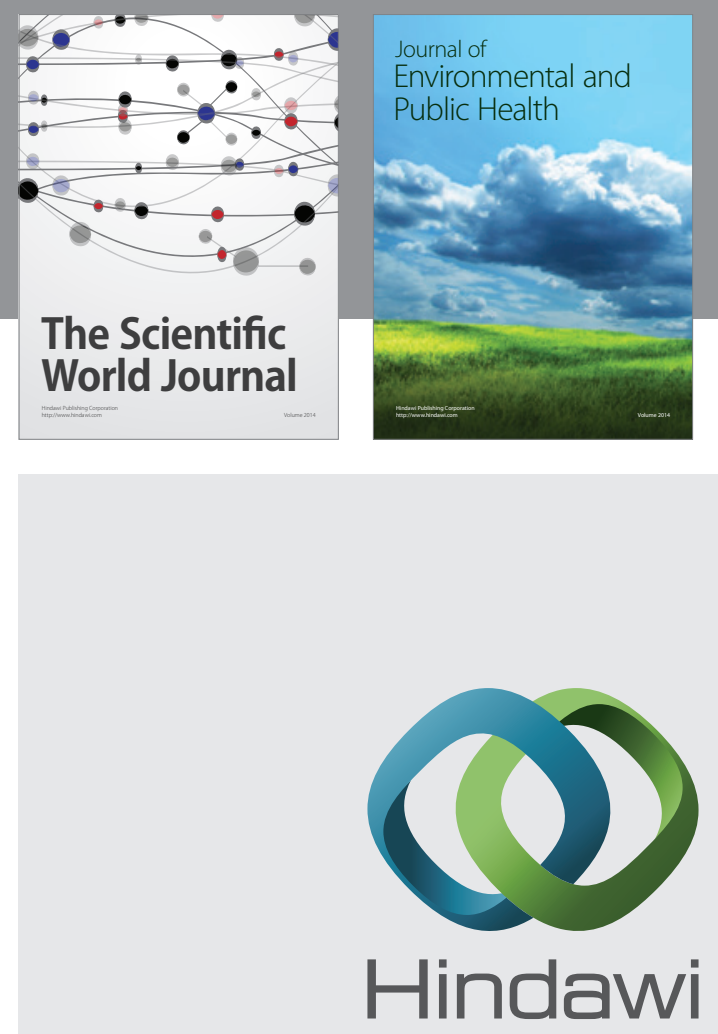

Submit your manuscripts at

http://www.hindawi.com
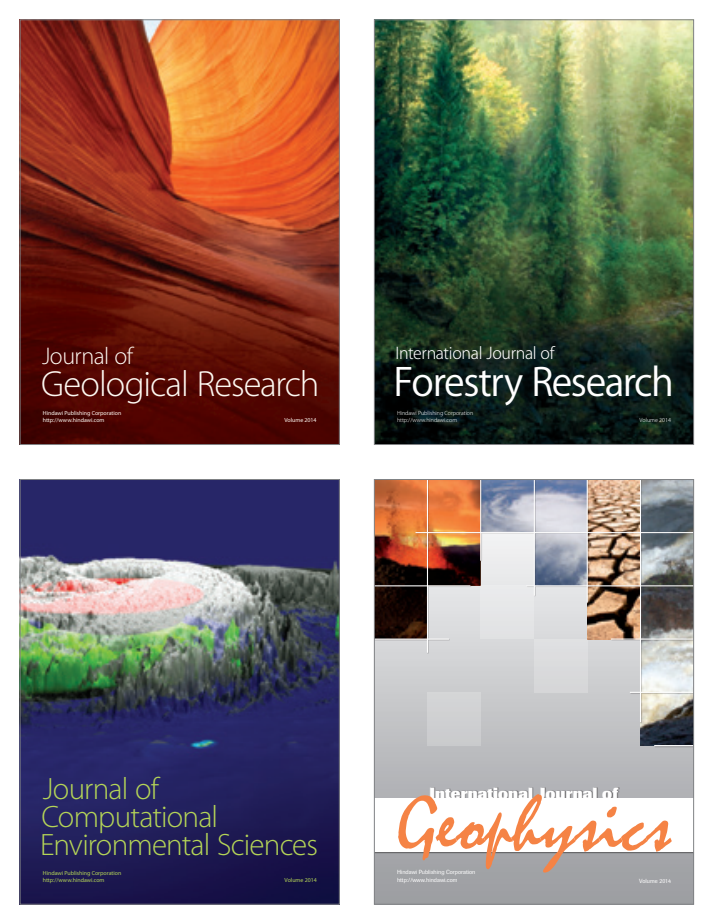
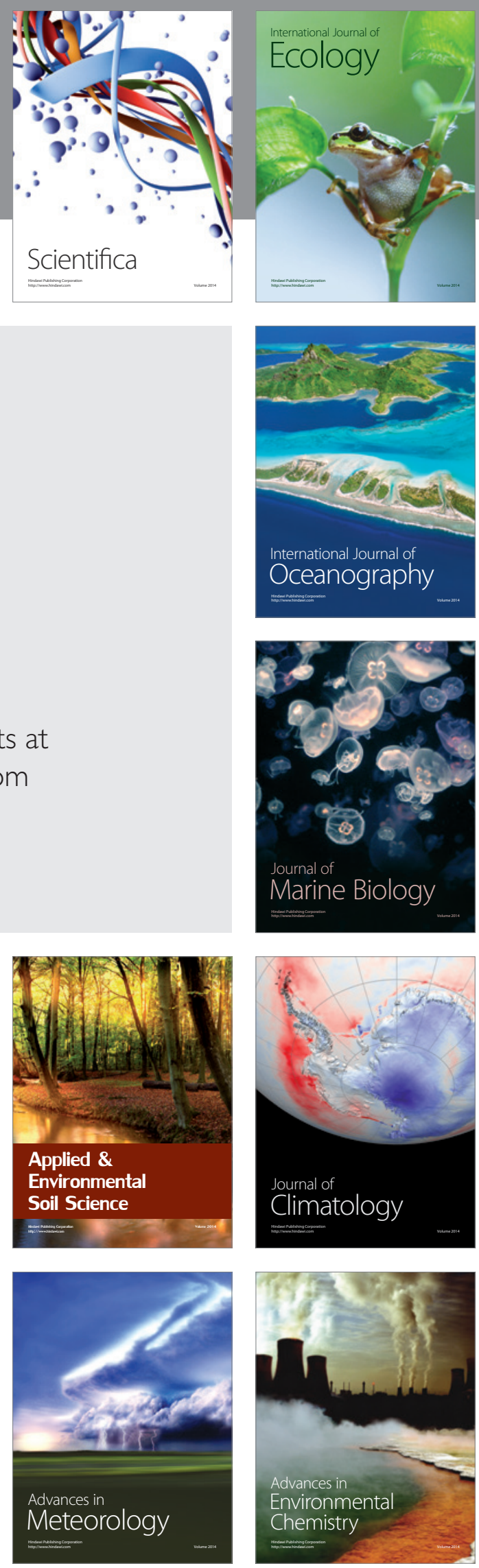